\title{
HERMENEUTIKA TEOLOGI PENTAKOSTA
}

\author{
JEFRI HINA REMI KATU
}

\begin{abstract}
$\underline{\text { Pendahuluan }}$
Istilah hermeneutic berasal dari kata Yunani hermeneuo, yang berarti menyampaikan (suatu pikiran atau keinginan), menjelaskan (suatu ucapan), dan menerjemahkan (sesuatu dari satu bahasa ke bahasa yang lain). Kata ini berhubungan dengan Dewa Hermes yaitu dewa dalam mitologi Yunani yang bertugas menyampaikan berita dari para dewa kepada manusia sebagai penerimanya. 1 Hermeneutik selalu digunakan sebagai ilmu pengetahuan serta seni dari penafsiran kitab Suci.2 Penting untuk diperhatikan bahwa hermeneutik berkaitan erat dengan kajian-kajian alkitabiah, seperti, kajian kanon, kritik teks, kritik historis, eksegesis, teologi alkitabiah serta teologi sistematis. 3
\end{abstract}

Kaum Injili sangat kosisten dalam metode hermeneutik mereka untuk memahami teks-teks Alkitab. Meskipun demikian, konsistensi mereka menjadi tantangan tersendiri bagi kaum pentakosta. Pentakostalisme merupakan gerakan yang bisa dikatakan sebagai gerakan yang baru dalam kekristenan, khususnya dalam tradisi Injili, gerakan ini telah menjadi suatu gerakan kekristenan yang cukup berkembang pada masa kini.

Pentakosta merupakan salah satu aliran kekristenan yang perkembangannya begitu populer. Jumlah penganut Pentakosta di dunia dalam sebuah riset pada tahun 2002 sekitar 500 juta, dengan sebuah penyebaran geografis yang sangat luas.4 Dalam riset yang dilakukan oleh

1 Henry A. Virkler, Hermeneutics: Principles and Processes of Biblical Interpretation (Grand Rapid, MI: Baker Book House, 1981), 15.

2 Bernard Ramm, Protestant Biblical Interpretation, third edition (Grand Rapid, MI: Baker Book House, 1970), 1 see also Virkler, Hermeneutics, 16.

3 Ramm, Protestant Biblical Interpretation, 7-10.

4 Alister E. McGrath, The Future of Christianity, (Malden, Massachusetts: Blackwell Publisher, 2002), 108. 
Todd M. Johnson, Gina A. Zurlo, Albert W. Hickman dan Peter F. Crossing pada tahun 2017 menyebutkan bahwa jumlah kaum

Pentakosta/Karismatik di dunia kira-kira 669 juta.5 Jumlah ini mengalami peningkatan dari riset sebelum yang pernah dilakukan. Pentakosta adalah bagian dari aliran kekristenan yang mulai berkembang pada awal tahun 19016 dan sampai saat ini telah menjadi gerakan kekristenan yang berkembang dengan cepat.

Keunikan dari perkembangan gerekan Pentakosta adalah pada penekanan cara mereka memahami Kitab Kisah Para Rasul dalam realitas konteks mereka. Douglas Petersen mengatakan bahwa kaum Pentakosta membaca dan menafsirkan teks-teks kitab Suci dengan melihat ke belakang dan kedepan dalam pengalaman mereka terhadap teks-teks tersebut di mana mereka menarik sebuah aplikasi praktis. Dengan kata lain, kaum Pentakosta menafsirkan kitab Suci dan pada saat yang sama memunculkan proses aplikasi praktis dalam konteks mereka dalam komunitas iman untuk dilakukan.7 Tentu hermeneutika kaum Pentakosta dalam membaca dan memahami teks-teks kitab Suci menjadi rujukan bagi mereka dalam menjalankan aplikasi praktis mereka.

Selain itu, dalam perkembangannya yang signifikan pada masa kini, Kaum Pentakosta mendapatkan tantangan yang berkaitan dengan hermeneutika yang menjadi panduan dasar mereka dalam menjelaskan teologi pentakosta yang unik kepada kaum Injili yang kerap kali memandang kaum Pentakosta tidak memiliki konsep teologi yang rasional. Hal ini dikarenakan kaum Pentakosta lebih menekankan emosi dari pada rasio. Tantangan ini dikarenakan bagaimana kaum Pentakosta dapat menjelaskan konsep teologi mereka sebagai praktek spiritualitas mereka seperti doktrin glossolalia serta pengalaman adikodrati yang berkaitan dengan intervensi

\footnotetext{
5 Todd M. Johnson, Gina A. Zurlo, Albert W. Hickman and Peter F. Crossing, "Christianity 2017: Five Hundred Years of Protestant Christianity:” International Bulletin of Mission Research, (South Hamilton, MA, 2017), 6. http://www.gordonconwell.edu/ockenga/research/documents/IBMR2017.pdf. Accesed on March 13, 2018.

6 Untuk pembacacaan lebih lanjut mengenai sejarah perkembangan gerakan Pentakosta lihat John Thomas Nichol, The Pentecostal, (Plainfield, New Jersey: Logos International, 1971), 26.

7 Douglas Petersen, “Three Challenges to Pentecostal Social Action:” Asian Journal of Pentecostal Studies [AJPS 16:1 (2013), 52.
} 
ilahi dari karya Roh Kudus sebagai bagian dari pemberdayaan umat TUHAN.

Pada peristiwa Pentakosta dalam Kisah Para Rasul 1 dan 2, Allah mencurahkan Roh-Nya untuk memenuhi murid-murid-Nya, dan melalui mereka Allah bersabda dengan suatu cara yang belum pernah dipakai-Nya, yakni suara bahasa-bahasa adikodrati.8 Tujuan dari pencurahan Roh Kudus pada hari Pentakosta adalah untuk menuai jiwa yang diproklamirkan melalui pemberitaan Injil serta kesaksian dari para murid yang menerima Baptisan Roh Kudus.

Pengalaman adikodrati inilah yang menjadi dasar pemahaman dari Gerakan Penkosta pada abad ke 20. Gerakan ini dimulai pada tahun 1901 yang diawali dengan pengalaman Agnes Osman yang dipenuhi oleh Roh Kudus.9 Pengalaman adikodrati ini diungkapkan oleh Charles Parham yang merupakan guru dari Agnes Osman di Sekolah Alkitab di Topeka, Kansas.

I laid my hands upon her and prayed," Parham later recalled of the event. "I had scarcely complated three dozen sentences when a glory fell upon her, a halo seemed to surround her head and face, and she began speaking the Chiness language and was unable to speak English for three days. 10

Dari pengalaman ini terjadi sebuah pembaharuan dalam memberitakan Injil. Pertumbuhan dari kelompok pentakosta saat ini mempunyai dampak yang signifikan dalam pertumbuhan gereja. Seperti yang diungkapkan oleh Gary B. McGee bahwa kisah gerakan misi pentakosta pada penyebaran telah mendunia saat ini.11 McGee menambahkan bahwa sebagaimana Allah "menunda" kedatangan-Nya, kaum Pentakosta menyadari bahwa bangunan gereja Kristus memerlukan lebih pelayanan tanda-tanda dan

\footnotetext{
8 Holland, 9.

9 Vinson Synan. The Century of the Holy Spirit: 100 Years of Pentacostal and Charismatic Renewel, (Nashville: Thomas Nelson Publisher, 2001), 1. On Januari 1, 1901, a young women named Agnes Ozman was baptized in the Holy Spirit at small Bible School in Topeka, Kansas. A Student of former Methodist pastor and holiness teacher Charles Fox Parham, Ozman received a startling manisfestation of the gift of tongues and became, in effect, the first Pentacostal of the $20^{\text {th }}$ century. 10 Ibid.

11 Vinson Synan, ed. The Century of the Holy Spirit: 100 Years of Pentacostal and Charismatic Renewel, by Gary B. McGee (Nashville: Thomas Nelson Publisher, 2001), 94.
} 
mukjizat-mukjizat.12 Fenomena pelayanan semacam ini memberikan implikasi terhadap karakteristik aplikasi hermeneutik Teologi Pentakosta.

Kaum Pentakosta telah mulai memikirkan hermeneutik mereka untuk membangun sebuah teologi yang dapat dipertanggung jawabkan secara alkitabiah. Tentu hermeneutik kaum Pentakosta tidak lepas dari prinsip hermeneutik Injili karena pada dasarnya Pentakosta merupakan bagian dari kaum Injili. Karena itu, Kaum Pentakosta memikirkan prinsip hermeneutik sebagaimana yang dikatakan oleh Ramm bahwa kebutuhan primer dari hermeneutik adalah untuk menegaskan apa yang Allah telah katakan di dalam Kitab Suci dan untuk menentukan/memutuskan makna dari Firman Allah tersebut.13 Kebutuhan sekunder dari hermeneutik sebagaimana yang Ramm tekankan adalah untuk menjembatani pemikiran-pemikiran kita dan pemikiran-pemikiran para penulis Alkitab.14 Dengan demikian, kaum Pentakosta bisa menjelaskan dasar teologi mereka berdasarkann bagaimana mereka memahami kitab Suci yang sedikit lebih unik dari kaum Injili meskipun prinsip-prinsip penafsirannya mengikuti metode-metode hermeneutik Injili.

Sehubungan dengan kebutuhan primer dan sekunder dari hermeneutik alkitabiah, maka sangat penting untuk menemukan metode-metode penafsiran secara khusus dalam perspektif Pentakosta. Paper ini akan berfokus pada bagaimana cara kaum Pentakosta menggunakan atau memahami serta mengembangkan Teologi Pentakosta yang berdasarkan pada pendekatan hermeneutis mereka yang uniks.

\section{Perlunya Hermeneutika}

Tidak dapat disangkal bahwa gerakan Pentakosta mula-mula memiliki akar-akar yang kuat dari Gerakan Kekudusan Wesleyan (Wesleyan Holiness Movement) yang berkaitan dengan kebangunan kembali (kebangunan

12 Ibid.

13 Ibid., 2.

14 Ibid., 4.

12 | P a g e 
rohani) Kekristenan pada abad ke-20. Sebagaimana yang dikatakan oleh Kenneth J. Archer bahwa Pentakosta adalah kelanjutan dari praktek Wesleyan holiness di mana sebuah hermeneutik Pentakosta telah muncul. Untuk memahami metode hermeneutik Pentakosta mula-mula, Pentakostalisme perlu diuji dalam konteks sejarah yang telah memunculkan perdebatan Fundamentalist/Modernist).15 Tantangan ini adalah untuk mendorong kaum Pentakosta untuk memikirkan ulang pemahaman teologi mereka berkaitan dengan pengalaman mereka terhadap Kitab Suci serta menjadi acuan bagi non-Pentakosta untuk memahami bagaimana kaum Pentakosta sendiri membaca teks-teks Kitab Suci.

Archer menambahkan bahwa Gerakan Pentakosta dan Wesleyan Holiness memiliki konsep yang sama berkenaan dengan natur Alkitab dan signifikansi dari pengalaman personal dalam hal untuk menegaskan inspirasi supernatural dari Alkitab.16 Karena itu, kaum Pentakosta dan tradisi Kekudusan (holiness) menekankan pada karya inspirasi dari Roh Kudus baik pada masa lampau penulisan Kitab Suci maupun pada pengalaman masa kini dengn teks Kitab Suci.17 Roh Kudus memampukan Kitab Suci untuk berbicara kepada komunitas masa kini melalui membaca dan menghidupi teks-teks Kitab Suci tersebut. Pada bagian lain, kaum Fundamentalis menekankan bahwa karya inspirasi dari Roh Kudus hanya pada dokumen tertulis masa lampau dari Kitab Suci.18 Menurut Archer, hal ini merupakan perbedaan antara pemahaman kaum Pentakosta dengan Fundamentalis berkenaan dengan karya inspirasi dari Roh Kudus di dalam kehidupan orang-orang Kristen. Bagi kaum Pentakosta, Roh Kudus memiliki peran yang sama dalam inspirasi Kitab Suci baik pada masa lampau maupun masa kini, tetapi kaum Fundamentalis menekankan hanya pada tulisan-tulisan masa lampau.

Karya inspirasi Roh Kudus bagi pembaca masa kini yang diungkapkan oleh Archer tidak dapat diterima. Charles Hodge mengatakan, "inspiration was 
an influence of the Holy Spirit on the minds of certain select men, which rendered them the organs of God for the infallible communication of his mind and will' (bahwa karya inspirasi merupakan pengaruh Roh Kudus pada pikiran orang-orang terpilih, yang telah menjadikan mereka alat Allah untuk komunikasi yang tidak berkesalahan dari pikiran dan kehendakNya).19 Karena itu, John Jefferson Davis menjelaskan bahwa istilah inspirasi harus dibedakan dari istilah pewahyuan dan iluminasi.

Pewahyuan merujuk kepada tindakan atau perkataan asli Allah dengan mana Allah mengkomunikasikan pikiran dan kehendak-Nya. Inspirasi merujuk kepada proses di mana wahyu yang diterima dari Allah ditulis dan disampaikan kepada umat Allah. Sedangkan iluminasi merujuk kepada karya Roh Kudus dalam membantu para pembaca untuk memahami makna dan signifikansi dari firman Allah yang tertulis.20

Dalam sebuah ulasan terhadap tulisan Archer, Jason E. Vickers menyampaikan bahwa kebanyakan akademisi Pentakosta telah menggunakan serta mempraktekkan hermeneutik mereka dari perspektif Injili. Sebagai konfirmasi yang populer bahwa Pentakosta dikategorikan sebagai bagian dari kaum Injili.21 Karena itu, adalah tidak tepat menggunakan istilah "inspirasi" dalam memahami teks Alkitab sebagaimana yang diungkapkan oleh Archer.

French L. Arrington mengatakan bahwa jantung dari Pentakosta mula-mula menekankan bahwa keseluruhan isi Kitab Suci adalah Allah. Keyakinan ini menegaskan bahwa Alkitab adalah wahyu Allah yang dapat dipercaya.22 Pemahaman kaum Pentakosta serta penafsiran Alkitab berbeda dengan penafsiran Injili. Gordon Anderson mengatakan,

Pentecostals are a unique hybrid of conservative commitments to the inspiration and authority of Scripture, confidence in the Bible, and the

19Charles Hodge, Systematic Theology, vol. 1, ebook (Grand Rapids, MI: Christian Classics Ethereal Library, 2005), 154.

20 John Jafferson Davis, Foundation of Evangelical Theology (Grand Rapids, MI: Baker House, 1984), 173.

21 Kenneth J. Archer, Review A Pentecostal Hermeneutic for the Twenty-First Century: Spirit,

Scripture, and Community, by Jason E. Vickers, pneuma: The Journal of the Society for Pentecostal Studies, Volume 28, No 2, Fall 2006, 384.

22 French L. Arrington, "Feedback: Pentecostal Hermeneutic," Pneuma. The Journal of the Society for Pentecostal Studies, Vol. 16, No. 1, Spring 1994, 101. 
possibility of ascertaining its meanings with clarity. But at the same time they are exploring hermeneutical methods that present different ways of determining the meaning of the Bible.

(Pentakosta merupakan sebuah "cangkokan" yang unik dari komitmen-komitmen konservatif terhadap inspirasi dan otoritas Kitab Suci, kepercayaan di dalam Alkitab, dan kemungkinan memastikan artinya dengan jelas. Namun pada saat yang sama mereka menyelidiki metode-metode hermeneutik yang menyajikan cara-cara yang berbeda dalam menentukan makna Alkitab).23

Pemahaman Pentakosta terhadap Kitab Suci menekankan lebih kepada dimensi pengalaman dalam keberadaan Allah melalui kehadiran Roh Kudus.

French L. Arrington menjelaskan, "A fundamental principle of Pentecostal hermeneutics is: Scripture given by the Holy Spirit must be mediated interpretively by the Holy Spirit" (sebuah prinsip fundamental dari hermeneutik Pentakosta adalah: Alkitab yang diberikan oleh Roh Kudus harus ditengahi dengan penafsiran oleh Roh Kudus).24 Carsten Aust mengatakan bahwa pemahaman Pentakosta terhadap Kitab Suci melampaui sekedar sisi kognitif atau proposional dari kebenaran, tetapi membuatnya juga experiential.25

Alkitab merupakan Firman Allah yang dipertimbangkan sebagai kebenaran ilahi yang mengubahkan kehidupan setiap orang Kristen. Arrington menegaskan bahwa pemahaman Pentakosta terhadap kebenaran teks Kitab Suci adalah bukan hanya untuk menyingkapkan kebenaran tetapi juga untuk menerapkan kebenaran tersebut di dalam komunitas orang beriman yang mana mereka membagikannya kepada orang lain dan hati mereka bergerak ke arah Allah (move toward God). Kemampuan untuk membagikan kebenaran Alkitab adalah berdasarkan pada pengalaman terhadap Roh Kudus untuk membaca dan mempelajari Kitab Suci dan

23 Gordon Anderson, "Pentecost, Scholarship, and Learning in a Postmodern World," Pneuma: The Journal of the Society for Pentecostal Studies, Volume 27, No 1, Spring 2005, 119.

24 French L. Arrington, "Feedback: Pentecostal Hermeneutic," Pneuma. The Journal of the Society for Pentecostal Studies, Vol. 16, No. 1, Spring 1994, 104.

25 Carsten Aust, Comparing Pentecostal Hermeneutical Elements to the Anglo-American Evangelical and Postmodern Hermeneutical Tradition of Hans-Georg Gadamer: A Selective Analysis, Thesis (Baguio City, PH: Asia Pacific Theological Seminary, August 2008), 38. 
mengijinkan kebenaran-kebenaran tersebut mengubahkan kehidupan mereka.26 Karena itu, dasar bagi iman serta praktek Pentakosta telah didasarkan pada teks Alkitab.27 Dengan kata lain, pemahaman Pentakosta terhadap kebenaran adalah untuk mengaktualisasikan teks Alkitab ke dalam diri mereka.28

Pentakosta klasik memiliki suatu penafsiran literal yang ekstrim terhadap Kitab Suci. Sebagai contoh, mengendalikan ular serta minum racun yang mematikan adalah sebuah pembacaan yang literal terhadap Markus 16.29 Penafsiran mereka dibentuk di dalam sebuah cara literal tanpa menguji konteks historis dari teks Kitab Suci tersebut.30 Karena itu, Archer mengatakan bahwa adalah sebuah subyek yang penting bagi kaum Pentakosta karena hermeneutika memiliki fokus perhatian kepada metode eksegesis yang membentuk sebuah pemahaman teologis yang didasarkan pada metode kritis-historis terhadap Kitab Suci.31

Hal inilah yang merupakan kebutuhan bagi hermeneutik khususnya bagi kaum Pentakosta, sebuah tugas untuk membaca Kitab Suci tanpa mengabaikan kritik-konteks historis dari Kitab Suci tersebut. Pada bagian yang lain, tugas ini akan membantu kaum Pentakosta untuk memahami lebih dalam makna dari teks-teks Alkitab tanpa mengabaikan dimensi pengalaman personal ketika membaca Kitab Suci melalui karya "iluminational" dari Roh Kudus pada pembacaan masa kini.

Sandra M. Schneider menjelaskan bahwa pendekatan Historical criticism terhadap Kitab Suci akan menolong untuk memahami makna yang dimaksudkan dari penulis dan dipahami oleh pembaca mula-mula, sehingga teks tersebut mungkin berarti bagi pembaca kontemporer sebagai sebuah proses aplikasi dari pembaca sekarang ini yang mana para pembaca

26 Arrington, “Feedback: Pentecostal Hermeneutic," 107.

27 Ibid., 101.

28 Aust, Comparing Pentecostal Hermeneutical Elements, 43.

29 Kenneth J. Archer, "Pentecostal Hermeneutics: Retrospect and Prospect, ” Journal of Pentecostal Theology, 4 no 8 Apr 1996, 65.

30 Ibid., 66.

31 Kenneth J. Archer, "Pentecostal Story: The Hermeneutical Filter for the Making of Meaning," The Journal of the Society for Pentecostal Studies, Volume 26, No. 1, Spring 2004, 36. 
telah diubahkan melalui percakapan dengan teks tersebut. Dialog dengan teks Kitab Suci memiliki multi penafsiran yang mana hal itu memberikan sebuah makna yang kaya bagi para pembaca.32 Schneider menekankan scientific criticis $m$ terhadap Kitab Suci adalah penting,33 tetapi hal itu tidak cukup. Pendekatan scientific criticism hanya menekankan peran manusia daripada peran Roh Kudus sebagai mediator yang mana para pembaca dapat berdialog dengan teks dan memampukan mereka untuk memahami makna dari teks tersebut pada masa kini mereka.

Pengalaman personal dengan Roh Kudus memiliki sebuah peran yang sangat signifikan untuk membantuk para pembaca untuk memahami makna dari teks Alkitab melalui percakapan mereka dengan teks tersebut. Percakapan dengan teks muncul melalui pertanyaan, "what did it mean?" dan "what does it mean?" Pertanyaan pertama merujuk pada historical criticism dari sebuah teks. Sedangkan pertanyaan yang kedua merujuk kepada pertanyaan aplikasi kepada pembaca masa kini. Sebagaimana yang Peter A. Sutcliffe katakan,

"The contemporary interpreter, in order address the issue of what the Scripture does it mean, must first address the issue of what it did mean." (Penafsir kontemporer, dalam rangka mengatasi masalah apa yang sesungguhnya dimaksudkan oleh Alkitab, terlebih dahulu harus mengatasi masalah apa yang dulu dimaksudkan).34

Maksud Sutcliffe adalah bahwa terdapat maksud penulis yang ditujukan kepada para pembaca mula-mula yang patut dipertimbangkan oleh pembaca masa kini. Karena itu, hermeneutik diperlukan, dalam kaitannya dengan dampak pengaruh ilahi atas para penulis dan tulisan-tulisan mereka, oleh para penafsir masa kini. Pengaruh ilahi dalam penulisan Kitab Suci merupakan intervensi Roh Kudus ke atas para penulis dan memampukan mereka untuk mengomunikasikan pesan-pesan ilahi kepada para pembaca mula-mula. Komunikasi dengan teks-teks Alkitab pertama-

32 Sandra M. Schneider's, "Does the Bible Have a Postmodern Message?" Postmodern theology: Christian faith in a pluralist world, San Francisco : Harper \& Row, 1989, 61-62.

33 Ibid., 63.

34 Peter A. Sutcliffe, Is there an Author in This Text? Discovering the Otherness of the Text (Eugene, OR: Wipf and Stock Publishers, 2014), 13. 
tama perlu mempertimbangkan komunikasi para penulis Alkitab melalui tulisan-tulisan mereka kepada para pembaca mereka. Interaksi pembaca masa kini terhadap teks-teks Kitab Suci merupakan bentuk komunikasi para pembaca masa kini sebagai suatu bentuk tindakan kritik historis dari teks-teks kitab Suci agar mampu memahami maksud mula-mula dari sebuah teks dan dapat menarik sebuah aplikasi praktis pada masa kini.

Selain melakukan sebuah kritik historis dari teks-teks Kitab Suci, kaum Pentakosta menekankan intervensi ilahi dalam pembacaan teks-teks Kitab Suci. Hal ini berkaitan dengan karya Roh Kudus atas pembaca masa kini dalam membaca serta menafsirkan Kitab Suci. William W. Menzies mengatakan bahwa gerakan Pentakosta modern mendemonstrasikan tempat yang substansial dari karya Roh Kudus dalam kehidupan gereja menjadi pola utama dari teologi orthodox yang bersejarah yang berjalan berdampingan. Oleh sebab itu, teologi Pentakosta dengan pasti adalah pengalaman pribadi dengan Roh Kudus.35 Jadi Menzies mengungkapkan bahwa peperangan (the battle) teologis saat ini terletak pada isu pokok yang berkaitan dengan Pentecostal Hermeneutics.36

Menzies mengajukan sebuah kerangka holistik untuk metodologi dalam hermeneutik Pentakosta. Kerangka holistik tersebut dijelaskan dalam tiga level. Pertama, level induktif. Level hermeneutik ini menekankan pada sebuah keterampilan ilmiah terhadap penafsiran Kitab Suci yang mana para pembaca masa kini mendengarkan kepada arti serta maksud dari para penulis Kitab Suci dan yang dapat dimengerti oleh para pembaca mulamula. Terdapat tiga prinsip berkaitan untuk mendengarkan Kitab Suci, yakni, beberapa teks Kitab Suci adalah declarative/menyatakan yang mana beberapa teks merupakan pernyataan langsung, implikasional yang berarti beberapa teks menyiratkan doktrin, dan deskriptif bahwa Kitab Suci ditulis dalam gaya penulisan narrative. 37

35 William Menzies, "The Methodology of Pentecostal Theology: An Essay on Hermeneutics," In Essay on Apostoloc Themes: Studies in Honor of Howad M. Ervin Presented to Him by Colleagues and Friends on His Sixty-Fifth Birthday, edited by Paul Elbert (Peabody, MA: Hendrickson, 1985), 1.

36 Ibid., 4.

37 Ibid., 5-6. 
Kedua, level deduktif. Kitab Suci harus ditafsirkan dalam dua arah.

Pertama melalui investigasi terhadap arti/makna dari teks melalui kritik historis dari teks, pada saat yang bersamaan, tema dan pengajaran dari Kitab Suci yang datang untuk membawa dampak pada teologi alkitabiah, sebagai contoh pada Kitab Kisah Para Rasul berkaitan dengan konsep subsequence38 dan normatif, yang mengiringi tanda bahasa lidah menjadi bermakna.39

Ketiga, level verifikasi/pembuktian.40 Roger Stronstad mengatakan bahwa hal ini merupakan level pengalaman kontemporer.41 Bagi Menzies, "Jika kebenaran Alkitabiah adalah untuk diajarkan, maka hal itu seharusnya dibuktikan dalam kehidupan."42 Level ini menekankan bahwa pengalaman tidak mengembangkan sebuah teologi, tetapi pengalaman harus mendemonstrasikan sebuah kebenaran teologis.43 Level verifikasi yang ditekankan oleh Menzies adalah untuk menunjukkan kepada kaum Injili bahwa kaum Pentakosta tidak membangun teologi mereka berdasarkan pengalaman, namun ekspresi-ekspresi pengalaman mereka dengan Roh Kudus merefleksikan pemahaman teologi mereka akan karya Roh Kudus yang memenuhi orang-orang percaya yang merefleksikan doktrin Baptisan Roh Kudus dari perspektif Pentakosta.44 Menzies memberikan kontribusi yang signifikan terhadap hermeneutika Pentakosta. Orang-orang Pentakosta harus membaca Kitab Suci tanpa mengabaikan metode ilmiah dari penafsiran Kitab Suci untuk mengembangkan pemahaman teologis mereka. Kaum Pentakosta percaya secara khusus serta mengembangkan

\footnotetext{
38 Lih. Bill and Bob Menzies, Spirit and Power, 109-118. Doktrin subsequence yang dikembangkan oleh kalangan Pentakosta merupakan doktrin yang menekankan "Baptisan Roh Kudus" sebagai anugerah Pentakosta yang lebih bersifat karismatik daripada soteriologis. Karena itu, pemahaman Pentakosta mengenai baptisan Roh Kudus secara logis berbeda dari karya pertobatan.

39 Ibid., 10-11.

40 Ibid., 12.

41 Roger Stronstad, Spirit, Scripture, and Theology: A Pentecostal Perspective (Baguio City, PH: Asia Pacific Theological Seminary Press, 1995), 29.

42 Ibid., 13.

43 Ibid., see also Stronstad, Spirit, Scripture, and Theology, 29.

44 Sebagai tambahan bahwa kaum Injili memberikan definisi berbeda mengenai Baptisan Roh Kudus dengan bagaimana Kaum Pentakosta memahaminya. Bagi kaum Injili, Baptisan Roh Kudus merupakan bagian dari karya soteriologis dari Roh Kudus. Sedangkan kaum Pentakosta memahami bahwa Baptisan Roh Kudus merupakan karya Roh Kudus atas umat TUHAN untuk memberdayakan mereka dalam menjalankan misi Allah. Dengan demikian, baik Injili maupun Pentakosta memahami Baptisan Roh Kudus secara berbeda.
} 
pemahaman teologis mereka terhadap Kitab Lukas dan Kisah Para Rasul. Pada bagian yang lain, pengalaman Pentakosta harus mendemonstrasikan kebenaran teologis dalam kehidupan sehari-hari.

Howard M. Ervin menekankan pada pneumatic epistemology di dalam hermeneutik Pentakosta. Dia menjelaskan bahwa Kitab Suci sebagai firman Allah dalam hermeneutik Pentakosta. Dia menjelaskan bahwa Alkitab sebagai firman Allah adalah mengenai the spoken existential word (2 Pet. 1:21) dan firman yang tertulis. Karena itu, firman Allah tidak dapat dibagi dari sebuah literatur suci atau Kitab Suci (2 Tim. 3:15).45 Lebih lanjut, dia menekankan bahwa kesaksian dari Kitab Suci merupakan pesan yang tidak lain dari pada intervensi ilahi Roh Kudus.46 Pemahaman Pentakosta mengenai pneumatic hermeneutic adalah respon eksistensial dan fenomenologis terhadap karya Roh Kudus di dalam kontinusitas historis dengan kehidupan Roh Kudus di dalam gereja.47

Pengalaman dengan Roh Kudus memberikan kesadaran eksistensial terhadap keajaiban di dalam world view alkitabiah. Kesadaran tersebut adalah berkaitan dengan pengalaman kontemporer dari kesembuhan ilahi, nubuatan, mujizat, serta exorcism sebagai bukti empiris dari pengalaman gereja-gereja Pentakosta.48 Kesadaran ini berdampak terhadap hermeneutik Pentakosta yang memiliki penekanan pada pengalaman pneumatic dengan Kitab Suci. Sebagai mana yang Stronstad ungkapkan,

"because Scripture is Spiritual, and because it must be spiritually appraised. It could only be understood with the contemporary help of the Spirit" (karena Kitab Suci adalah Spiritual, maka hal itu harus

\footnotetext{
45 Howard M. Ervin, "Hermeneutics: A Pentecostal Option," Essay on Apostolic Themes: Studies in Honor of Howad M. Ervin Presented to Him by Colleagues and Friends on His Sixty-Fifth Birthday, edited by Paul Elberth (Peabody, MA: Hendrickson Publishers, 1985), 28.

46 Ibid., 33. Pneumatic epistemology dalam penjelasan Ervin merupakan sebuah kesadaran bahwa Kitab Suci merupakan prodak-prodak dari pengalaman para penulis Alkitab dengan Roh Kudus yang mana para penulis menguraikannya dalam bahasa fenomenologis. Pengalaman pneumatic dari para penulis telah melahirkan Kutab Suci. Karena itu, konsekuensi bagi hermeneutic Pentakosta adalah sebuah rasa hormat terdalam terhadap kesaksian Kitab Suci terhadap diri mereka sendiri dan mereka membaca Kitab Suci tersebut dalam pengalaman pneumatic continuity dari komunitas iman.

47 Ibi., 34.

48 Ibid., 35.
} 
dinilai secara spiritual. Hal itu hanya dapat dipahami dengan bantuan Roh Kudus).49

Seorang pemikir Pentakosta lainnya yang bernama Gordon Fee menjelaskan bahwa hal tersebut harus menjadi sebuah aksioma bahwa hermeneutik alkitabiah yang mana Kitab Suci ditafsirkan harus mengambil literary genre dari teks yang ditafsirkan yang berkaitan dengan pertanyaan-pertanyaan terhadap teks, grammar, filologi,50 dan sejarah.51 Lebih lanjut, Fee menunjukkan bahwa isu-isu hermeneutik alkitabiah di kalangan Pentakosta adalah berkaitan dengan jenis sastra atau genre dari Kitab Suci tersebut. Fee menjelaskan bahwa historical narrative genre di dalam Kitab Suci bukanlah risalah teologis. Dia keberatan bahwa tulisan Lukas mengenai Kisah Para Rasul sebagai sebuah theological intent. 52

Namun I. Howard Marshall memiliki pandangan yang berbeda dengan Fee dalam kaitan dengan tulisan Lukas. Marshall menyarankan bahwa untuk membaca kitab Lukas dan Kisah Para Rasul harus dalam framework bahwa Lukas sebagai seorang sejarawan dan juga seorang teolog. Sebagai seorang teolog, perhatian Lukas di dalam pesan-pesannya mengenai Yesus dan gereja mula-mula adalah berdasarkan pada sejarah yang dapat dipercaya. Karena itu, teologinya didasarkan pada tradisi di mana dia mengevaluasi dan menggunakan cerita-ceritanya untuk menunjukkan teologinya.53 Jadi tulisan Lukas bukan sekedar sebuah laporan historis, melainkan juga pada saat yang sama, dia menekankan teologinya yang didasarkan pada laporan sejarah mengenai Yesus dan pengalaman gereja mula-mula dengan Roh Kudus. Sebagaimana yang dikatakan oleh Gordon L. Anderson, “In a good Pentecostal hermeneutics the narratives are seen as didactic and are

49 Stonstad, Spirit, Scripture, and Theology, 74.

50 Filologi merupakan ilmu tentang bahasa, kebudayaan, pranata, dan sejarah suatu bangsa sebagaimana terdapat dalam bahan-bahan tertulis.

51 Gordon Fee, Gospel and Spirit: Issue in New Testament Hermeneutics (Peabody, MA: Hendrickson Publishers, 1994), 89.

52 Ibid., 90.

53 I. Howard Marshall, Luke: Historian and Theologian (Grand Rapids, MI: Zondervan Publishing House, 1971), 18-19. 
used to build theology" (dalam sebuah hermeneutik Pentakosta yang baik, narasi dilihat sebagai didactis dan digunakan untuk membangun teologi).54

\section{$\underline{\text { Penggunaan Kitab Suci oleh kaum Pentakostal }}$}

Scott A. Ellington menjelaskan bahwa kecenderungan orang-orang Pentakosta jatuh kembali pada kesaksian akan pengalaman pribadi. Kisah mereka diambil dari pengalaman pribadi mereka di mana Allah berbicara kepada mereka melalui perantaraan teks-teks Alkitab.55 Lebih lanjut, Ellington menekankan bahwa pengalaman Pentakosta adalah melampaui jangkauan evaluasi kritis. Pengalaman tanda-tanda dan mujizat-mujizat membuat mereka untuk membagikan kepada komunitas mereka melalui kesaksian. Otoritas Alkitab di seluruh gereja Pentakosta adalah pada pengalaman mereka dengan Allah di dalam dan melalui Kitab Suci dalam kehidupan sehari-hari.56 Gereja-gereja Pentakosta pada warisan Kristen umumnya adalah mengenai otoritas Alkitab, jadi gerakan Pentakosta dengan pasti alkitabiah. $57 \mathrm{Hal}$ ini menunjukkan bahwa pengalamanpengalaman Pentakosta merupakan pengalaman-pengalaman yang dapat dipertanggung jawabkan secara alkitabiah. Kaum Pentakosta menarik isi teks Kitab Suci ke dalam kehidupan sehari-hari untuk dialami karena teksteks Kitab Suci merupakan kebenaran yang harus dipraktekkan. Pengakuan akan kesahihan kebenaran Alkitab merupakan demonstrasi atas otoritas kitab Suci sebagai kebenaran. Hal ini mempengaruhi cara kaum Pentakosta membaca dan menafsirkan teks-teks Kitab Suci.

Tujuan dari membaca dan menafsirkan Kitab Suci dalam pemahaman kaum Pentakosta adalah untuk menemukan sesuatu yang dapat dialami

54 Gordon L. Anderson, "Pentecostal Hermeneutics: Part II," Paraclate, February 28, 1994, 16. 55 Scott A. Ellington, "Pentecostalism and the Authority of Scripture," Jurnal of Pentecostal Theology, 4 no 9 Oct 1996, 17. 56 Ibid., 21.

57 Nils Bloch-Hoel, The Pentecostal Movement: Its Origin, Development, and Distinctive Character (Norway: Scandinavian University Books, 1964), 98. 
yang relevan kepada kehidupan mereka.58 Karena itu, Allan Anderson mengatakan,

"Pentecostals believe in spiritual illumination, the experiential immediacy of the Holy Spirit who makes the Bible 'alive' and therefore different from any other book" (kaum Pentakosta percaya di dalam iluminasi spiritual, pengalaman kedekatan akan Roh Kuduslah yang membuat Alkitab 'hidup' dan karena itu berbeda dengan buku-buku yang lain). 59

Dalam penjelasan Anderson bagaimana orang-orang Pentakosta membaca Alkitab, pengalaman Alkitab berfokus pada intervensi ilahi dari Roh Kudus dalam kehidupan sehari-hari melalui pembacaan Alkitab dan memiliki sebuah aplikasi yang signifikan pada masa kini. Karena itu, pemahaman orang-orang Pentakosta terhadap Alkitab secara konstan menekankan terjadinya mujizat-mujizat di dalam komunitas gereja tentang bagaimana Alkitab terhubung kepada pengalaman sehari-hari mereka.60

Robert P. Menzies menekankan bahwa, "Pentecostal experience and practice is driven and sharped by the Bible" (pengalaman dan praktek kaum Pentakosta adalah digerakkan dan dipertajam oleh Alkitab).61 Lebih lanjut, hermeneutik Pentakosta adalah "straightforward and simple: The story in Acts is my stories that were written to serve as models for shaping my life and experience" (lugas dan sederhana: Kisah dalam kitab Kisah Para Rasul adalah kisah-kisah saya, yang ditulis untuk menjadi model-model untuk membentuk kehidupan dan pengalaman saya).62 Dengan kata lain, kaum Pentakosta mengaitkan pengalaman-pengalaman orang-orang percaya dalam Kitab Suci, secara khusus dalam kitab Kisah Para Rasul, dengan pengalaman masa kini. Pengalaman para rasul dalam Kisah Para Rasul masih relevan dan berlaku bagi pengalaman orang-orang percaya pada masa kini. Itulah sebabnya kaum Pentakosta meyakini bahwa karya-karya Allah yang memberdayakan para murid melalui kepenuhan Roh Kudus atas

58 Alland Anderson, An Introduction to Pentecostalism (Cambridge, UK: Cambridge University Press, 2004), 225. 
umat TUHAN pada Kisah Para Rasul masih berlaku sampai saat ini. Tentu pemahaman inilah yang memberikan keyakinan kepada kaum Pentakosta militan dalam menjalankan misi Allah di mana kaum Pentakosta sangat militan dalam pelayanan pelepasan, mendoakan kesembuhan fisik, serta pelayanan-pelayanan kebangunan rohani yang membawa kelompok Pentakosta berkembang secara signifikan secara kuantitas.

Bob Menzies menyoroti keunikan dari pembacaan kaum Pentakosta terhadap Alkitab, secara khusus cara mereka membaca kitab Lukas-Kisah Para Rasul dalam sebuah cara yang berbeda dari pembacaan kaum Injili. Pada cara yang sama, kaum Pentakosta juga disebut Injili dalam artian bahwa kaum Pentakosta dan Injili menegaskan otoritas Alkitab dan menekankan maksud para penulis Alkitab dan berusaha mencari untuk memahami teks-teks Alkitab dalam terang historical-critical dan literary context.63 Hal ini sedang menunjukkan bahwa kaum Pentakosta menerapkan prinsip-prinsip penafsiran Alkitab dengan melakukan sebuah kritik historis dari teks-teks Kitab Suci. Selain itu, kaum Pentakosta menunjukkan kesetiaannya terhadap otoritas Alkitab sebagai sumber kebenaran yang patut dipraktekkan dalam kehidupan Kristiani. Di sinilah letak kesetiaan kaum Pentakosta terhadap otoritas kebenaran Alkitab sebagai panduan kehidupan Kristiani.

\section{$\underline{\text { Menekankan Pengalaman pada Teks Kitab Suci }}$}

Kaum Pentakosta menekankan pada karya Roh Kudus dalam kehidupan orang-orang percaya. Karena itu, tujuan dari hermeneutik Pentakosta merupakan implementasi-implementasi dari pesan Alkitab di dalam kehidupan sehari-hari mereka. David F. Ford menjelaskan bahwa gerakan Pentakosta dan Karismatik sama-sama menekankan siginifikansi dari pengalaman dengan Roh Kudus yang dengan jelas diekspresikan melalui intensive bodily participation in worship. Penyembahan dan doa merupakan praktek yang "berlebihan" yang dihubungkan dengan gagasan 
overwhelmed by God. Karena itu, percakapan antara teks Alkitab dan konteks dari komunitas adalah sebuah dimensi khusus dari sebuah pendekatan di dalam pengalaman dengan Roh Kudus melalui penafsiran dari teks yang sedang dibaca. 64

Kaum Pentakosta menekankan pengalaman pribadi kepada Alkitab melalui karya Roh Kudus, jadi pengalaman ini dapat diuraikan sebagai sebuah pengalaman religious yang disahkan sebagai kebenaran ilahi.65 Alkitab adalah kebenaran Allah, jadi konsep kebenaran harus dipahami sebagai bukti eksperimental yang berlaku secara universal. Bukti eksperimental ini merupakan sebuah solusi yang menjanjikan sesuatu yang pantas, bukti yang diverifikasi dalam keberadaan Allah dan kebenaran Kekeristenan. Oleh sebab itu, sebagai bukti, maka semua referensi mujizat xenolalia, di mana kelompok Pentakosta telah alami dapat meyakinkan pengalaman ecstatics dirinya sendiri dan orang-orang yang telah menyaksikan fenomena tersebut. 66

Timothy B. Cargal menjelaskan bahwa kaum Pentakosta lebih menekankan pada peran pengalaman dari penafsir dalam lingkaran hermeneutis (hermeneutical circle).67 Lingkaran hermeneutis yang dimaksudkan oleh Cargal adalah bahwa penafsiran dan pengalaman dari sebuah teks tidak bisa dipisahkan. Dengan kata lain, penafsir membaca teks-teks Alkitab dan mengaitkan dengan pengalaman penafsir. Karena itu, Cargal tegaskan bahwa model penafsiran tersebut konsisten berkaitan dengan penekanan pengalaman yang dibangkitkan oleh posmodernisme.68 Lebih lanjut, Cargal menunjukkan bahwa hermeneutik kaum Pentakosta memusatkan pada sebuah pengalaman spiritual pada umumnya dan iluminasi pneumatic

64 David F. Ford, "Holy Spirit and Christian Spirituality," The Cambridge Companion to Postmodern Theology, edited by Kevin J. Vanhoozer (Cambridge, UK: Cambridge University Press, 2003), 285-288. See also William W. Menzies, "The Methodology of Pentecostal Theology: an Essay on Hermeneutics," Essay on Apostolic Themes: Studies in Honor of Howard M. Ervin Presented to Him by Colleagues and Friends on His Sixty-Fifth Birthday, edited by Paul Elbert (Peabody, MA: Hendrickson Publishers, no date), 1. There is uniqueness to Pentecostal theology. There is a precision and definiteness about the experience of the Spirit - clarity of expectation that can be proclaimed and demonstrated.

65 Bloch-Hoell, The Pentecostal Movement, 99.

66 Ibid., 100.

67 Timothy B. Cargal, "Beyond the Fundamentalist-Modernist Controversy: Pentecostal and Hermeneutics in a Postmodern Age," in Papers of the $21^{\text {st }}$ Annual Conference of the Society for Pentecostal Studies, 1991, 178. 68 Ibid., 179. 
khususnya untuk memahami Alkitab.69 Jadi, menurut Cargal, pengalaman dengan Roh Kudus cukup untuk dapat membantu pembaca masa kini dalam memahami teks-teks Kitab Suci. Presuposisi pembaca tidak dapat dilepaskan dalam membaca Kitab Suci dan pengalaman kebergantungan dengan Roh Kudus menjadi sarana untuk menjembatani makna teks Kitab Suci sebagai tulisan masa lampau dengan pemahaman masa kini. Jadi, iluminasi Pneumatic dari perspektif Pentakosta dalam membaca dan menafsirkan Kitab Suci merupakan peran utama dari pengalaman. Unsur pengalaman menjadi bagian dalam memahami Alkitab.

Hermeneutik Pentakosta menekankan pengalaman yang bersifat personal kepada pengalaman komunal melalui kuasa transformative dari Roh Kudus dalam kehidupan masing-masing pribadi, dalam komunitas iman dan di dalam dunia. Jadi kaum Pentakosta telah menemukan keyakinan mereka dalam ototritas Alkitab, bukan pada argumen doktrinal atau teologis, melainkan pada pengalaman pribadi, yang mana merupakan perjumpaan dengan Allah di dan melalui teks-teks Alkitab.70

Simon Chan memiliki sebuah argumen yang menarik mengenai pengalaman Pentakosta dengan Alkitab. Bagi Chan, kaum Pentakosta menekankan lebih kepada dynamic view dari karya Roh Kudus yang mana Roh Kudus telah memimpin orang-orang percaya untuk mengerti Alkitab. Alkitab sebagai kebenaran menjadi rhema melalui karya Roh Kudus dan menerapkan Alkitab untuk kehidupan pribadi. Karena itu, dalam pemahaman Pentakosta, kebenaran adalah supernatural karena karya Roh Kudus dalam kehidupan orang percaya.71 Hermeneutik Pentakosta

69 Ibid., 180. See also Scott A. Ellington, "Pentecostalism and the Authority of Scripture," 18. "Pentecostalism begins with intense experiences of encountering God. God reveals Himself in the pages of the Bible, in signs and wonders, in worship and prayer in very real and powerful ways. Pentecostals understanding of the Scripture is base their faith in God through the personal relationship with God. This relationship could be articulated as a personal experience with God and they share to others. Therefore, Pentecostalism is the experience of the community of faith."

70 Ellington, "Pentecostalism and the Authority of Scripture," 30.

71 Simon Chan, Pentecostal Theology and the Christian Spiritual Tradition (Sheffield, EN: Sheffield Academic Press, 2000), 108. Cf. Kevin J. Vanhoozer, "Theology and the Condition of Postmodernity: a Report on Knowledge (of God)," The Cambridge Companion to Postmodern Theology (Cambridge, UK: Cambridge University Press, 2003), 164-165. "Gereja adalah mewujudkan Alkitab, karena itu gereja merupakan sebuah komunitas yang mempraktekkan kebenaran yang telah dibentuk dan dimampukan oleh Roh Kudus. Alkitab merupakan kesaksian Roh Kudus kepada gereja mengenai Yesus Kristus, satu Pribadi yang membuat Bapa 
memasukkan pengalaman pribadi dalam memahami Alkitab. Karena itu, bagi Anderson, pengalaman ini dilihat sebagai ekspresi Kekristenan yang menekankan dan menghargai pengalaman pribadi dengan dimensi hubungan dengan Allah.72

Pengalaman pribadi dengan Alkitab dalam hermeneutik Pentakosta adalah penting karena pengalaman ini sebagai bagian dari dimensi hubungan pribadi dengan Allah. Hal tersebut tidak dapat dielakkan bahwa kaum Pentakosta sangat ekspresif dalam memberikan respon kepada teks Alkitab sebagai sebuah teks yang dibaca sebagai sebuah rhema dan menerapkannya di dalam kehidupan mereka, sebagai bagian dari pengalaman mereka dengan Alkitab. Penekanan terhadap pengalaman dengan teks-teks Kitab Suci merupakan bagian yang penting dalam kehidupan spiritualitas Kristiani. Karena itu, hermeneutik Pentakosta memberikan ruang terhadap pengalaman pribadi dengan kebenaran teksteks Kitab Suci.

Namun, penekanan terhadap pengalaman perlu mendapat perhatian agar tidak terjebak dalam budaya posmodern yang menekankan unsur pengalaman pada pembacaan terhadap sebuah teks. Suatu teks yang dibaca akan menjadi kebenaran jika dikonfirmasi dengan pengalaman. Dengan kata lain, penekanan terhadap unsur pengalaman akan membangkitkan kebenaran yang bersifat relatif sebagaimana posmodernisme tegaskan bahwa tidak ada kebenaran yang absolut karena kebenaran harus bersumber dan sesuai dengan pengalaman.

\section{Tantangan-tantangan baru untuk Hermeneutika Pentakostal}

Hermeneutik Posmodern telah menjadi sebuah tantangan baru bagi hermeneutika Pentakosta. Jean-François Lyotard dengan sangat tegas

\footnotetext{
dikenal dan satu Pribadi yang menyelesaikan karya kehendak salfivic Bapa. Dengan kata lain, Alkitab merupakan kesaksian Kristus sendiri kepada diri-Nya sendiri melalui komisi perwakilan para nabi dan rasul yang telah menuliskan Alkitab dalam kuasa Roh Kudus. Alkitab adalah komunikasi ilahi Allah untuk menyingkapkan diri-Nya sendiri dan Roh Kudus merupakan agen untuk memahaminya."

72 Gordon L. Anderson, "Pentecostal Hermeneutics Part II," 19.
} 
menjelaskan bahwa hermeneutik posmodern merupakan keraguan terhadap metanarratives mengenai kebenaran secara ilmiah dalam perspektif modern.73 Bagi Lyotard, perspektif posmodern mengenai kebenaran adalah,

"It refines our sensibility to differences and reinforces our ability to tolerate the incommensurable" (hal tersebut menyaring kepekaan kita terhadap perbedaan dan menguatkan kembali kemampuan kita untuk mentoleransi yang tidak dapat dibandingkan).74 Penafsiran mengenai kebenaran yang Hans-Georg Gadamer, sebagai seorang postmodernist, menekankan bahwa kebenaran harus dipahami dalam dimensi pengalaman manusia.75 Pengalaman manusia adalah penting dalam masyarakat untuk memahami dunia. Oleh sebab itu maka bahasa merupakan pengetahuan manusia yang esensial. Selanjutnya Gianni Vattimo menunjukkan bahwa kebenaran dalam perspektif postmodern adalah didasarkan pada penafsiran pengalaman manusia.76 Gadamer menekankan hermeneutik pengalaman untuk memahami makna sebuah teks. Bagi Gadamer, konsep kebenaran dan teks dalam bahasa manusia harus dipahami dalam pengalaman akan kebenaran itu sendiri. Gadamer mengungkapkan bahwa,

"The experience of the world in language is 'absolute.' It transcends all the relativities of positing of being, because it embraces all being-initself, in whatever relationships (relativities) it appears" (pengalaman akan dunia di dalam bahasa adalah 'absolut.' Hal itu melampaui semua yang bersifat relatif dari apa yang telah ada, karena ia merangkum semua keberadaan itu didalamnya, dalam bentuk hubungan apapun (yang bersifat relatif) di mana ia muncul). 77

\footnotetext{
73 Jean-François Lyotard, “The Postmodern Condition,” Philosophy: a New Introduction, edited by Doulas Mann and G. Elijah Dann (Belmont, CA: Wadsworth/Thomson Learning, 2005), 790. Pemikiran rasional merupakan pahlawan pengetahuan dalam modernism dan metanarasi yang menyatakan secara tidak langsung kepada filosofi sejarah yang digunakan untuk pengetahuan yang sah/legitimate knowledge. Pertanyaanpertanyaan muncul mengenai keabsahan/validitas dari lembaga yang mengatur ikatan social: hal-hal ini harus disahkan juga. Jadi, keadilan diserahkan kepada narasi agung dengan cara yang sama sebagai kebenaran. 74 Ibid., 791.

75 Hans-Georg Gadamer, "Rhetoric, Hermeneutics, and the Critique of Ideology: Metacritical Comments on Truth and Methode," The Hermeneutics Reader, edited by Kurt Mueller-Vollmer (New York: Continuum, 2000), 274.

76 Gianni Vattimo, "The Truth of Hermeneutics and 'the Decline of the Subject and the Problem of Testimony," Truth Engagements Across Philosophical Traditions, edited by Josè Medina and David Wood (Malden, MA: Blackwell Publishing, 2005), 170.

77 Hans-Georg Gadamer, Truth and Method (New York: Crossroad Publishing Company, 1982), 408-421. "The concept of being-in-itself acquires the character of a definition of the will. What is exists in itself is independent of one's own willing and imagining. But in being known in its being-in-itself, it is made available in the sense
} 
Hermeneutik pengalaman adalah mengenai bahasa dan penafsiran teks yang menghubungkan kepada kebenaran. Bagi Gadamer, kebenaran dinyatakan/dibuktikan dalam pertunjukkan linguistic dari penafsiran dan fenomena bahasa serta pemahaman. Dengan kata lain, kebenaran terletak di dalam apa yang manusia katakan berdasarkan pada situasi dan konteks dari pembicara kepada apa yang sedang dikatakan.78 Karena itu, kebenaran dalam perspektif posmodern adalah konseptual berdasarkan pada situasi dan konteks dari seseorang yang sedang berbicara.

Konteks dari hermeneutik pengalaman adalah komunitas-komunitas manusia. Robert S. Corrington menjelaskan bahwa komunitas-komunitas berhubungan kepada struktur-struktur horizontal dari penafsiran dalam hal itu hermeneutik dikaitkan dengan lokasi setiap penafsiran dalam lokasi dan tradisi yang tepat.79 Berkaitan dengan pengalaman manusia, setiap momen yang mereka miliki memperkenalkan persepsi dan konteks yang baru di mana yang baru dan yang dikenal adalah terus-menerus berinteraksi. Setiap pengalaman secara konstan mengubah pemikiran dan pola pengalaman yang sebelumnya telah dikembangkan.80 Kebenaran dalam hermeneutik posmodern terkait erat dengan respon total terhadap pengalaman. Karena itu, pengetahuan dan kebenaran yang bersifat subyektif tidak dapat dihindarkan.

Cargal mengatakan bahwa, "Pentecostalism does have something to contribute to the postmodern discourse about the Bible - in particular within the Church" (Pentakostalisme memiliki sesuatu untuk berkontribusi terhadap wacana postmodern mengenai Alkitab - khususnya dalam gereja).81 Lebih lanjut, Cargal menegaskan bahwa peran dari pengalaman

\footnotetext{
that one can deal with it, i.e., use it for one's own purpose." Therefore, Gadamer emphasizes that language is the nature of the human experience and human language being formed and developed that expresses in the experience of present world.

78 Ibid., 445.

79 Robert S. Corrington, The Community of Interpreters: on the Hermeneutics of Nature and the Bible in the American Philosophical Tradition (Macon: Mercer University Press, 1987), 48. See also Gadamer, Truth and Method, 401-402. "The original humanity of language means at the same time the fundamental linguistic quality of man's being-in-the-world. We shall to investigate the relationship between language and the world in order to attain the horizon adequate to the linguistic nature of the hermeneutical experience."

80 Clarence Walhout, "Narrative Hermeneutics," The Promise of Hermeneutics, (Grand Rapids, MI: William B. Eerdmans Publishing House, 1999), 81.

81 Cargal, "Beyond the Fundamentalist-Modernist Controversy: Pentecostal and Hermeneutics in a Postmodern Age," 186.
} 
kaum Pentakosta adalah membentuk dan dibentuk oleh penafsiranpenafsiran tertentu dari teks-teks Alkitab yang cocok dengan pandanganpandangan posstrukturalis82 tertentu dari pembaca sebagai pencipta kritik objektif yang signifikan dan penting yang memandang makna Alkitab dan otoritasnya.83

Pada bagian yang lain, para penganut Pentakosta telah ditantang untuk menerima, walaupun rasionalisme tidak dapat memberitahukan segala sesuatu mengenai makna dari teks-teks kitab Suci, secara khusus mengenai jarak sejarah dan budaya yang sebenarnya memisahkan pembaca sekarang dengan teks-teks Alkitab.84 Karena itu, Cargal menekankan bahwa kaum Pentakosta harus bersedia untuk mendengarkan dan dipimpin oleh Roh Kudus dalam penafsiran Alkitab yang diinformasikan oleh isu-isu kontemprer.85

Persoalan dengan pandangan Cargal adalah bahwa dia menggabungkan hermeneutik posmodern dengan hermeneutik Pentakosta. Bagi Cargal, jika hermeneutik apapun tidak berkaitan dengan paradigma posmodern, maka makna dari sebuah teks adalah tidak masuk akal dan irrelevant.86 Menzies melakukan kritik terhadap pendekatan Cargal. Cargal telah menantang hermeneutik Pentakosta untuk menolak makna sejarah dari teks Alkitab dan lebih memusatkan perhatian pada reader oriented sebagaimana yang posmodern lakukan.87 Karena itu, dalam pendekatan Cargal akan sulit untuk menemukan kebenaran yang absolut, sebagaimana kaum Pentakosta sejatinya meyakini bahwa Alkitab berisi kebenaran yang absolut.

\footnotetext{
82 Postrukturalis merupakan orang-orang yang terlibat dalam gerakan linguistic yang berpandangan bahwa hubungan antara unsur bahasa lebih penting daripada unsur itu sendiri, satu-satunya objek bahasa adalah system bahasa, dan penelitian bahasa dapat dilakukan secara sinkron

83 Cargal, Ibid., 186

84 Ibid.

85 Walhout, "Narrative Hermeneutics," 22. The contemporary issues that the Pentecostals should be aware are feminist movement, liberation theologians, and others whose political and theological agendas we may not always support.

86 Cargal, "Beyond the Fundamentalist-Modernist Controversy: Pentecostal and Hermeneutics in a Postmodern Age," 187.

87 William W. Mezies and Robert P. Menzies, Spirit and Power: Foundations of Pentecostal Experience (Grand Rapids, MI: Zondervan Publishing House, 2000), 63.
} 
Selain itu, terdapat kemiripan dalam spiritualitas Pentakosta dan Posmodern. Kemiripan tersebut adalah sama-sama memberikan penekanan pada conviction dalam hal memperoleh atau mendapatkan apa yang diinginkan. Vines mengungkapkan bahwa pengalaman iman Pentakosta terkadang disebut "Name it claim it," "health and wealth," prosperity gospel," "positive confession," "word of faith."88 Praktek iman semacam ini berkembang dalam kalangan Pentakosta yang biasa disebut Teologi Kemakmuran. Tetapi dalam pengalaman iman Pentakosta, Crabtree mengatakan bahwa pengalaman Pentakosta bukanlah sifat dasar dari keselamatan, penerimaan terhadap kebenaranlah yang sangat penting bagi kehidupan rohani dan esensial kepada sifat khusus Pentakosta.89

Pengajaran Teologi Kemakmuran biasanya muncul karena dasar pemahaman bahwa Allah menginginkan orang-orang percaya untuk memperoleh segala sesuatu yang terbaik.90 Hal senada diungkapkan oleh Nichol:

The cornerstone of "deliverance evangelism," as it was referred to among Pentecostals, is the belief that just as God wants everyone to be saved from sin, so also does He desire everyone to be well. The task of deliverance evangelists, therefore, is to proclaim this truth and encourage their listeners to believe it. 91

Terdapat indikasi bahwa penderitaan, kekurangan, bahkan hal-hal yang buruk disebabkan oleh karena dosa. Dosalah yang menjadi pemisah antara Allah dengan manusia sehingga manusia mengalami hal-hal yang buruk. Tetapi Allah menginginkan hal-hal yang terbaik harus dialami oleh manusia. Jadi demonstrasi atas pemulihan dari penderitaan merupakan manisfestasi pembebasan Allah terhadap ikatan-ikatan tersebut.

Positive thinking dalam posmodernisme hampir mirip dengan praktek iman yang berkembang dalam spiritualitas pentakostalisme. Karakteristik

88 Jerry Vines, Spirit Works: Charismatic Practices and the Bible (Nashville, Tennessee: Broadman \& Holman Publishers, 1999), 159.

89 Charles T. Crabtree, The Pentacostal Priority (US: National Decade of Harvest, 1993), 20-21.

90 Vines, Spirit Works, 159

91 John Thomas Nichol, The Pentecostal (New Jersey: Logos International, 1966), 222. 
dari spiritualitas posmodernisme adalah positivisme. Positivisme merupakan suatu praktek keyakinan yang berlebihan. Istilah lain yang cocok dengan positivisme adalah fideism.92

Robert C. Greer mengatakan bahwa secara teknis, fideism berarti faith in faith (iman di dalam iman). Keyakinan ini merupakan tindakan berpikir positif yang mengarah kepada sesuatu yang diyakini untuk memperoleh atau mendapatkan kebenaran.93 Greer menambahkan bahwa fideism adalah sebuah konsep yang memiliki keyakinan pada diri sendiri, mengandalkan sistem faith in faith. Hal tersebut kerapkali dihubungkan dengan iman yang dicirikan oleh kenaifan, kesederhanaan berpikir, dan pemikiran yang penuh harapan.94

Gerakan Pentakosta sering dihubungkan dengan pelayanan kesembuhan di dalam gereja. Pelayanan ini mempunyai pengaruh yang signifikan dalam gereja. Seseorang akan mengalami kesembuhan, baik kesembuhan fisik maupun non-fisik seperti kerasukan hanya melalui iman.

Gerakan pengajaran iman mulai berkembang di kalangan kelompok Pentakosta. Kesembuhan ilahi yang dialami karena iman merupakan suatu berkat yang diperoleh dari Allah. Menurut Mark J. Cartledge konsep iman yang dikembangkan adalah faith formula atau positive confession, 95 atau dengan kata lain, Name it claim it. Positive confession (pengakuan/ ungkapan positif) merupakan formula iman dari spiritualitas posmodernisme, sedangkan name it claim it merupakan formula iman dari spiritualitas pentakostalisme. Keduanya hampir sulit dibedakan.

Meskipun kedua spiritualitas ini terdapat kemiripan, namun harus disadari bahwa keduanya berbeda secara esensial. Perbedaan dari keduanya adalah bahwa spiritualitas pentakostalisme mempunyai correct focus (fokus yang benar). Fokus yang benar inilah yang membuat pentakostalisme mempunyai kebenaran yang objektif dan absolut,

\footnotetext{
92Fideism merupakan sebuah paham yang menekankan keyakinan yang bersifat positif terhadap sesuatu yang sadari dapat memberikan sebuah keadaan yang baik. 93Robert C. Greer, Mapping Postmodernism: a Survey of Christian Option (Downers Grove, Illinois: InterVarsity Press, 2003), 236 94 Ibid. 95 Mark J. Cartledge, Practical Theology: Charismatic and Empirical Perspectives (Carlisle, Cumbria: Paternoster Press, 2003), 201.
} 
sedangkan dalam spiritualitas posmodernisme tidak mempunyai correct focus sehingga pada akhirnya mereka mempunyai kebenaran yang jamak, atau dengan kata lain mempunyai kebenaran yang relatif. Correct focus dari pentakostalisme adalah Alkitab sebagai Firman Allah yang merupakan sumber kebenaran yang absolut. Pemahaman ini merupakan warisan pentakosta yang diterima dari pemikiran Injili yang memandang kepada otoritas Alkitab sebagai Firman Allah yang telah diwahyukan.

Dasar dari sumber kebenaran menjadi perbedaan dari kedua spiritualitas ini. Sumber kebenaran posmodernisme adalah manusia, sedangkan pada pentakostalisme sumber dari kebenaran adalah Allah sendiri yang mewahyukan diri-Nya di dalam Alkitab. Dengan sangat jelas perbedaan ini memberikan awasan bahwa spiritualitas pentakostalisme tidak dipengaruhi oleh budaya spiritualitas postmodernisme.

Namun yang perlu diperhatikan dalam spiritualitas pentakostalisme adalah praktek dari formula iman yang sedang berkembang. Praktek pengajaran iman yang berlebihan mungkin akan membawa orang Kristen khususnya kelompok Pentakosta pada incorrect focus (focus yang tidak tepat).

Incorrect focus yang dimaksudkan di sini adalah orang akan cenderung berfokus pada mujizat serta karya-karya spektakuler, bukan berfokus kepada Allah. Atau dengan kata lain, terjadi devaluasi terhadap iman. Iman seharusnya berfokus kepada Allah dalam karya keselamatannya dalam sejarah, namun justru akan diartikan dengan berfokus kepada memperoleh setiap keinginan-keinginan atau ambisiambisi pribadi. Allah memang bekerja dalam karya-karya spektakuler dalam tanda dan mujizat yang menjadi semangat pelayanan dalam spiritualitas pentakostalisme, tetapi harus dilihat dalam kerangka karya penyelamatan Allah dalam sejarah.

\section{Simpulan}

Salah satu contoh kasus yang sering menjadi fenomena ekstrim dalam pelayanan Pentakosta adalah peperangan rohani. Pesan dari tindakan peperangan rohani yang dilakukan oleh kelompok Pentakosta menekankan 
satu sisi dari karya Yesus Kristus dalam kehidupan orang percaya. Oleh sebab itu, para pengkhotbah Pentakosta juga harus memberikan perhatian pada hermeneutik teologi Pentakosta. Hal ini bukan berarti bahwa tindakan peperangan rohani yang dilakukan adalah salah, melainkan tindakan tersebut harus merefleksikan pemahaman teologis yang sehat terhadap teks-teks Alkitab. Kristus telah memenuhi setiap orang percaya dengan Roh Kudus untuk memberdayakan mereka bagi pekerjaan misi Allah. Misi Allah adalah agar setiap orang percaya membagikan Injil kepada setiap orang.

Peperangan rohani mengambil satu bagian dari misi Allah di mana hal ini merupakan kabar baik yang dapat memulihkan bagi orang yang sakit, yang hidup dalam kemelaratan, serta mereka yang dikuasai oleh roh jahat. Namun pesan yang yang paling penting adalah untuk memimpin orang kepada hubungan pribadi dengan Kristus yang memberikan keselamatan dan kehidupan yang kekal.

Teks Alkitab merupakan sumber utama untuk mengenal siapa Kristus. Karena itu, pengalaman pribadi dengan Alkitab dalam hermeneutik Pentakosta adalah penting sebab pengalaman ini merupakan dimensi hubungan pribadi dengan Allah. Hal ini tidak terelakkan bahwa kaum Pentakosta menunjukkan respon yang sangat ekspresif terhadap teks Alkitab sebagai sebuah teks yang sedang dibaca, menjadi sebuah rhema dan menerapkannya dalam kehidupan mereka sebagai bagian dari pengalaman mereka terhadap Alkitab.

Paper ini mengundang para pengkhotbah Pentakosta untuk berpikir secara teologis dan praktis. Secara teologis berkaitan dengan penafsiran teks-teks Alkitab, dan secara praktis adalah bagaimana teks Alkitab menjawab kebutuhan umat Allah berdasarkan situasi mereka dan memimpin mereka kepada hubungan secara pribadi dengan Allah. 


\section{BIBLIOGRAPHY}

Anderson, Alland. An Introduction to Pentecostalism. Cambridge, UK: Cambridge University Press, 2004.

Anderson, Gordon L. "Pentecost, Scholarship, and Learning in a Postmodern World," Pneuma: The Journal of the Society for Pentecostal Studies, Volume 27, No 1, Spring 2005.

“Pentecostal Hermeneutics: Part II,” Paraclate, February 28, 1994, 13-22.

Archer, Kenneth J. "Pentecostal Hermeneutics: Retrospect and Prospect," Journal of Pentecostal Theology, 4 no 8 Apr 1996.

" "Pentecostal Story: The Hermeneutical Filter for the Making of Meaning," The Journal of the Society for Pentecostal Studies, Volume 26, No. 1, Spring 2004.

A Pentecostal Hermeneutic for the Twenty-First Century; Spirit, Scripture, and Community. New York, NY: T\&T Clark International, 2004.

Arrington, French L. "Feedback: Pentecostal Hermeneutic," Pneuma. The Journal of the Society for Pentecostal Studies, Vol. 16, No. 1, Spring 1994, 101-107.

Aust, Carsten. Comparing Pentecostal Hermeneutical Elements to the Anglo-American Evangelical and Postmodern Hermeneutical Tradition of Hans-Georg Gadamer: A Selective Analysis, Thesis. Baguio City, PH: Asia Pacific Theological Seminary, August 2008.

Bloch-Hoel, Nils. The Pentecostal Movement: Its Origin, Development, and Distinctive Character. Norway: Scandinavian University Books, 1964.

Cargal, Timothy B. "Beyond the Fundamentalist-Modernist Controversy: Pentecostal and Hermeneutics in a Postmodern Age," The Journal of the Society for Pentecostal Studies, Vol 15, No 2, Fall 1993, 163187.

Chan, Simon. Pentecostal Theology and the Christian Spiritual Tradition. Sheffield, EN: Sheffield Academic Press, 2000.

Corrington, Robert S. The Community of Interpreters: on the Hermeneutics of Nature and the Bible in the American Philosophical Tradition. Macon: Mercer University Press, 1987.

Crabtree, Charles T. The Pentacostal Priority. US: National Decade of Harvest, 1993.

Davis, John Jafferson. Foundation of Evangelical Theology. Grand Rapids, MI: Baker House, 1984.

Ellington, Scott A. "Pentecostalism and the Authority of Scripture," Jurnal of Pentecostal Theology, 4 no 9 Oct 1996, 16-38.

Ervin, Howard M. "Hermeneutics: A Pentecostal Option," Essay on Apostolic Themes: Studies in Honor of Howad M. Ervin Presented to Him by Colleagues and Friends on His Sixty-Fifth Birthday, edited by Paul Elberth. Peabody, MA: Hendrickson Publishers, 1985.

Fee, Gordon D. Gospel and Spirit: Issue in New Testament Hermeneutics. Peabody, MA:Hendrickson Publishers, 1994.

Ford, David F. "Holy Spirit and Christian Spirituality," The Cambridge Companion to Postmodern Theology, edited by Kevin J. Vanhoozer. Cambridge, UK: Cambridge University Press, 2003.

Gadamer, Hans-Georg. "Rhetoric, Hermeneutics, and the Critique of Ideology: Metacritical Comments on Truth and Methode," The Hermeneutics Reader, edited by Kurt Mueller-Vollmer. New York: Continuum, 2000.

Gadamer, Hans-Georg. Truth and Method. New York: Crossroad Publishing Company, 1982 
Hodge, Charles. Systematic Theology, vol. 1, ebook. Grand Rapids, MI: Christian Classics Ethereal Library, 2005.

Johnson, Todd M., Gina A. Zurlo, Albert W. Hickman and Peter F. Crossing, “Christianity 2017: Five Hundred Years of Protestant Christianity:" International Bulletin of Mission Research. South Hamilton, MA, 2017. http://www.gordonconwell.edu/ockenga/research/documents/IBMR2017.pdf.

Lyotard, Jean-François. "The Postmodern Condition,” Philosophy: a New Introduction, edited by Doulas Mann and G. Elijah Dann. Belmont, CA: Wadsworth/Thomson Learning, 2005.

Marshall, I. Howard Luke: Historian and Theologian. Grand Rapids, MI: Zondervan Publishing House, 1971.

Menzies, Robert P. Pentecost: this Story our Story. Springfield, MS: Gospel Publishing House, 2013.

Menzies, William W. “The Methodology of Pentecostal Theology: An Essay on Hermeneutics,” In Essay on Apostoloc Themes: Studies in Honor of Howad M. Ervin Presented to Him by Colleagues and Friends on His Sixty-Fifth Birthday, edited by Paul Elbert. Peabody, MA: Hendrickson, 1985.

. and Robert P. Menzies. Spirit and Power: Foundations of Pentecostal Experience. Grand Rapids, MI: Zondervan Publishing House, 2000.

Nichol, John Thomas. The Pentecostal. New Jersey: Logos International, 1966.

Ramm, Bernard. Protestant Biblical Interpretation, third edition. Grand Rapid, MI: Baker Book House, 1970.

Riggs, John W. Postmodern Christianity. New York, NY: Trinity Press International, 2003.

Satcliffe, Peter A. Is there an Author in This Text? Discovering the Otherness of the Text. Eugene, OR: Wipf and Stcok Publishers, 2014.

Schneiders, Sandra M. "Does the Bible Have a Postmodern Message?" Postmodern theology: Christian faith in a pluralist world, San Francisco: Harper \& Row, 1989.

Stronstad, Roger. Spirit, Scripture, and Theology: A Pentecostal Perspective. Baguio City, PH: Asia Pacific Theological Seminary Press, 1995.

Vanhoozer, Kevin J. "Theology and the Condition of Postmodernity: a Report on Knowledge (of God)," The Cambridge Companion to Postmodern Theology. Cambridge, UK: Cambridge University Press, 2003.

Vattimo, Gianni. "The Truth of Hermeneutics and 'the Decline of the Subject and the Problem of Testimony,"” Truth Engagements across Philosophical Traditions, edited by Josè Medina and David Wood. Malden, MA: Blackwell Publishing, 2005.

Vines, Jerry. Spirit Works: Charismatic Practices and the Bible. Nashville, Tennessee: Broadman \& Holman Publishers, 1999.

Virkler, Henry A. Hermeneutics: Principles and Processes of Biblical Interpretation. Grand Rapid, MI: Baker Book House, 1981.

Walhout, Clarence. "Narrative Hermeneutics," The Promise of Hermeneutics. Grand Rapids, MI: William B. Eerdmans Publishing House, 1999.

Biografi singkat

Penulis menyelesaikan studi pascasarjana di Asia Pacific Theology Seminary, Manila (APTS, www.apts.edu), dan kini sebagai pengajar tetap di STT Satyabhakti. 